\title{
TINJAUAN LITERATUR: PERSEPSI TENTANG JENIS DATA, SKALA DATA DAN HUBUNGANNYA DENGAN TEKNIK PEMBERIAN SKOR TES
}

\author{
Hendra Kartika \\ Program Studi Pendidikan Matematika, Fakultas Keguruan dan Ilmu Pendidikan, \\ Universitas Negeri Singaperbangsa Karawang, \\ Jln. H.S. Ronggowaluyo Telukjambe, Karawang-Jawa Barat 41361 \\ hend@scientist.com
}

\begin{abstract}
Abstrak. Sumber-sumber bacaan tentang statistika sudah banyak yang diterbitkan baik dalam bahasa asing maupun dalam bahasa Indonesia dengan pengarang yang berbedaberbeda. bagi pembaca ketika mencerna hasil bacaan dari suatu sumber akan menimbulkan persepsi yang berbeda-beda. Perbedaan makna dari hasil bacaan ini tentu akan menimbulkan pertentangan dan perdebatan.Dalam tulisan ini, penulis mencoba memaknai hasil bacaan statistika yang dilakukan penulis tentang jenis data, skala data dan hubungannya dengan teknik pemberian skor tes dari segi kajian literatur. Tujuannya adalah untuk mendapatkan respons dan menyamakan persepsi dikalangan peneliti, khususnya di kalangan para peneliti pendidikan.
\end{abstract}

Kata kunci. Statistika, jenis data, skala data, skor tes.

\section{Pendahuluan}

Sumber-sumber bacaan tentang statistika sudah banyak yang diterbitkan baik dalam bahasa asing maupun dalam bahasa Indonesia dengan pengarang yang berbeda-berbeda. Ketersediaan sumber bacaan yang melimpah ini tentu perlu diapresiasi, hal ini berarti budaya menulis dikalangan akademik maupun peneliti sudah sangat tinggi.

Namun, bagi pembaca ketika mencerna hasil bacaan dari suatu sumber akan menimbulkan persepsi yang berbeda-beda. Pembaca satu memaknai hasil bacaan dengan konsep $a$ sedangkan pembaca yang lain memaknai hasil bacaan dengan konsep $b$. Perbedaan makna dari hasil bacaan ini tentu akan menimbulkan pertentangan dan perdebatan. Terlebih jika pemaknaan ini digunakan untuk penelitian, tentu peneliti yang satu dengan peneliti yang lain akan menggunakan alat penelitian yang berbeda.

Dalam tulisan ini, penulis mencoba memaknai hasil bacaan statistika tentang jenis data, skala data dan hubungannya dengan teknik pemberian skor tes 
yang dilakukan penulis dari segi kajian literatur. Tujuannya adalah untuk mendapatkan respons dan menyamakan persepsi dikalangan peneliti, khususnya di kalangan para peneliti pendidikan.

\section{METODE PENELITIAN}

\section{Jenis Data}

Data dapat dibedakan dalam beberapa golongan tergantung dari sudut mana memandangnya. Berikut ini akan dibahas beberapa jenis data yaitu:

\subsection{Bentuk skor}

Data berdasarkan sifat angka atau skor dapat dibedakan menjadi dua golongan yaitu data diskrit dan data kontinu. Data diskrit sesuai dengan namanya memiliki ciri yang terpisah-pisah antara angka (bilangan) yang satu dengan angka yang terdekat lainnya atau data yang tidak berbentuk pecahan.

Contoh data diskrit yaitu; jumlah siswa pada tiap-tiap kelas, banyaknya mobil yang lewat pada setiap menit, skor hasil ujian 3-4-5-6-7-8. Untuk lebih jelasnya dapat dilihat pada deret data dibawah ini:

\section{9}

Data kontinu adalah data statistika yang angkanya merupakan deretan angka yang saling menyambung dari satu data ke data yang lainnya (kontinum). Untuk melihat memberikan gambaran secara visual dapat dilihat pada deretan angka berikut ini:

\section{7}

Contoh data kontinu yaitu, berat badan siswa SD kelas V adalah; 30,0 $34,134,2$ 34,3 34,4 34,5 34,6 34,7 34,8 34,9 40,00 dan seterusnya.

\section{Skala Data}

Skala adalah suatu ciri pada besaran atau variabel yang memungkinkan untuk dinyatakan dengan bentuk bilangan. Skala biasa digunakan dalam bidang pengukuran. Ada beberapa skala ukur antara lain; meter untuk jarak, detik untuk waktu, ampere untuk arus listrik, 0 dan 1 untuk menyatakan butir yang 
dijawab salah dan benar, 1 sampai10 pada ujian di SD, 1 sampai 5 untuk sikap. Stevens membagi skala ukur menjadi empat, yaitu; skala nominal, skala ordinal, skala interval, dan skala rasio.

\section{a. Skala Nominal}

Skala nominal, adalah skala ukur yang memiliki ciri hanya membedakan. Misal nomor telepon 2019574 tidak ada bedanya dengan nomor telepon 2012173, nomor rumah 13 dengan nomor 91, nomor induk mahasiswa 0809981 tidak berbeda dengan nomor 0809918. Pengkodean yaitu lakilaki diberi kode 1, dan perempuan dengan kode 2. Dari beberapa contoh yang ada, skala nominal tidak membedakan satu nomor atau kode dengan yang lain berbeda makna, semua pasangan data adalah sama.

\section{b. Skala Ordinal}

Skala ordinal, adalah skala data yang mempunyai ciri membedakan juga menunjukkan adanya peringkat. Misal juara pertama $=1$, juara ke dua $=2$, dan juara ke tiga $=3$. Lulusan $\mathrm{SD}=1$, lulusan $\mathrm{SMP}=2$, Lulusan $\mathrm{SMA}=$ 3.

Pada skala ordinal jarak diantara 1 ke 2 serta ke 2 ke 3 tidak harus sama jaraknya, maka jarak diantara skala sama atau tidak sama.

\section{c. Skala Interval}

Skala interval adalah skala data yang mempunyai ciri membedakan, menunjukkan peringkat dan berjarak sama.

Misal temperatur $24^{\circ} \mathrm{C}, 25^{\circ} \mathrm{C}, 26^{\circ} \mathrm{C}$.

Potensial - 2 volt, - 1 volt, 0 volt, 1 volt.

Jarak diantara $24^{\circ} \mathrm{C}$, ke jarak $25^{\circ} \mathrm{C}$, sama dengan jarak $25^{\circ}$ ke $26^{\circ} \mathrm{C}$ dan tidak memiliki titik 0 mutlak.

\section{d. Skala Rasio}

Skala rasio adalah skala data yang memiliki ciri; membedakan, menunjukkan peringkat, berjarak sama, dan memiliki titik 0 yang tulen atau mutlak. Misal banyaknya orang : 0 orang, 1 orang, 2 orang, 3 orang dan seterusnya
0
123 
Rasio $6: 2=3$,

$8: 2=4$ hasil bagi tersebut adalah tetap tidak berubah.

\section{Teknik Pemberian Skor}

Membuat pedoman penskoran sangat diperlukan, terutama untuk soal bentuk uraian dalam tes domain kognitif supaya unsur subjektivitas dalam memberikan skor dapat diperkecil.

\section{Pemberian Skor Tes pada Domain Kognitif}

\section{a. Penskoran Soal Bentuk Pilihan Ganda}

Cara penskoran tes bentuk pilihan ganda ada tiga macam, yaitu: pertama penskoran tanpa ada koreksi jawaban, penskoran ada koreksi jawaban, dan penskoran dengan butir beda bobot. Dalam pembahasan ini hanya terbatas pada penskoran tanpa koreksi.

1) Penskoran tanpa koreksi, yaitu penskoran dengan cara setiap butir soal yang dijawab benar mendapat nilai satu (tergantung dari bobot butir soal), sehingga jumlah skor yang diperoleh peserta didik adalah dengan menghitung banyaknya butir soal yang dijawab benar. Rumusnya sebagai berikut.

Skor $=\frac{B}{N} \times 100 \quad($ skala $0-100)$

$B=$ banyaknya butir yang dijawab benar

$N=$ banyaknya butir soal

Contohnya adalah sebagai berikut :

Pada suatu soal tes ada 50 butir, Budi menjawab benar 25 butir, maka skor yang dicapai Budi adalah:

$$
\text { Skor }=\frac{25}{50} \times 100=50
$$

\section{b. Penskoran Soal Bentuk Uraian Objektif}

Pada bentuk soal uraian objektif, biasanya langkah-langkah mengerjakan dianggap sebagai indikator kompetensi para peserta didik. Oleh sebab itu, sebagai pedoman penskoran dalam soal bentuk uraian 
objektif adalah bagaimana langkah-langkah mengerjakan dapat dimunculkan atau dikuasai oleh peserta didik dalam lembar jawabannya.

Untuk membuat pedoman penskoran, sebaiknya dilihat kembali rencana kegiatan pembelajaran untuk mengidentifikasi indikator-indikator tersebut. Perhatikan contoh berikut.

Indikator : peserta didik dapat menghitung isi bangun ruang (tabung) dan mengubah satuan ukurannya.

\section{Butir soal:}

Sebuah drum bensin berbentuk tabung dengan diameter $100 \mathrm{~cm}$ dan tinggi $70 \mathrm{~cm}$. Berapa literkah isi drum bensin tersebut? (untuk menjawabnya tuliskan langkah-langkahnya!)

Tabel 1. Pedoman Penskoran Soal objektif

\begin{tabular}{|c|c|c|}
\hline Langkah & \multicolumn{1}{|c|}{ Kunci Jawaban } & Skor \\
\hline 1 & $\begin{array}{l}\text { Diketahui: diameter tabung=100 cm; jari-jarinya }=\frac{1}{2} \times 100=50 \\
\text { cm } \begin{array}{c}\text { tinggi tabung=70 cm. } \\
2\end{array}\end{array}$ & 1 \\
3 & $\begin{array}{l}\text { Isitabung }=\pi \times r^{2} \times t \\
=\frac{22}{7} \times(50 \mathrm{~cm})^{2} \times 70 \mathrm{~cm} \\
=550.000 \mathrm{~cm}^{3}\end{array}$ & 1 \\
4 & $\begin{array}{l}\text { Isi drum bensin dalam liter: } \\
=\frac{550.000}{1000} \text { liter } \\
=550 \text { liter }\end{array}$ & 1 \\
5 & Skor Maksimum & 1 \\
\hline
\end{tabular}

\section{PEMBAHASAN}

Berdasarkan tinjauan pustaka diatas, dibahas beberapa pernyataan-pernyataan sebagai berikut:

1. Pemerintah melalui Kemendiknas untuk mengukur hasil belajar siswa secara nasional membuat standar penilaian dengan mengadakan Ujian 
Nasional (UN). Ujian nasional ini masih mendapat berbagai tentangan karena kemampuan siswa yang ada di daerah terpencil berbeda dengan kemampuan siswa yang ada di daerah perkotaan. Namun, jika UN tidak diberlakukan secara nasional, bagaimana pemerintah dapat mengukur keberhasilan pendidikan secara nasional?

2. Untuk mengukur hasil belajar siswa dibuatlah soal tes. Soal tes dapat berupa pilihan ganda, isian singkat ataupun uraian.

3. Bobot soal untuk pilihan ganda jika menjawab satu soal benar=1 sedangkan menjawab salah=0. Jadi jika terdapat 10 soal, siswa yang menjawab betul semua mendapat skor 10 sedangkan siswa yang menjawab salah semua mendapat skor 0. Sehingga skor maksimum yang dapat diperoleh adalah 10 sedangkan skor minimum 0. Seorang siswa dapat memperoleh skor diantara 0 dan $10(0 \leq S k o r \leq 10)$. Jadi skalanya 0 - 10. Skala ini dapat ditingkatkan ke skala 0 - 100 dengan menggunakan rumus: Skor $=\frac{B}{N} \times 100$.

Jumlah skor yang diperoleh peserta didik pada soal tes pilihan ganda tergantung pada banyaknya soal yang dijawab benar. Siswa yang mendapat skor 5 berbeda dengan siswa yang mendapat skor 9. Siswa yang mendapat skor 0 bukan berarti tidak mempunyai kemampuan sama sekali. Ada faktor yang mempengaruhi siswa pada saat mengerjakan soal ujian baik itu faktor psikologis maupun faktor lingkungan. Nilai skor antara siswa yang satu dengan siswa yang lain mempunyai jarak yang sama karena menggunakan alat ukur dan pedoman penskoran yang sama.

4. Bobot soal uraian, pada contoh diatas adalah 5. Jadi jika terdapat 5 soal dengan bobot yang sama, siswa yang menjawab betul semua mendapat skor 25 sedangkan siswa yang menjawab salah semua mendapat skor 0 . Sehingga skor maksimum yang dapat diperoleh adalah 25 sedangkan skor minimum 0. Seorang siswa dapat memperoleh skor diantara 0 dan 25 $(0 \leq S k o r \leq 25)$. Jadi skalanya $0-25$. Skala ini dapat ditingkatkan ke 
skala $\quad 0 \quad-\quad 100$ dengan menggunakan rumus: Skor_Total $=\frac{\sum_{i=1}^{n} \text { B.Soal }_{i}}{\sum_{i=1}^{n} \text { Skor.Maks }_{i}} \times 100$.

Keterangan:

$n=$ jumlah soal.

B.Soal ${ }_{i}=$ skor yang diperoleh pada soal ke- $i$.

Skor Maks $_{i}=$ skor maksimum soal ke- $i$.

Bolehkah bobot soal ini ditingkatkan? Atau bolehkah tiap soal mempunyai bobot yang bebeda-beda? Pada soal ujian di tingkat perguruan tinggi ada yang mencantumkan skor maksimum tiap soal seperti pada Gambar 1 berikut,

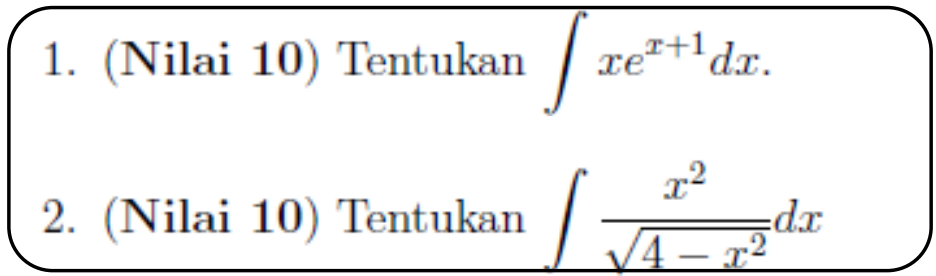

Gambar 1. Soal ujian dengan bobot 10

Pada dasarnya yang mengetahui tingkat kesulitan soal dan kemampuan peserta didik adalah guru atau dosen itu sendiri. Sehingga tidak jarang kita temukan pada soal ujian khususnya di perguruan tinggi ada yang mencantumkan bobot soal bahkan ada soal dengan bobot yang berbeda-beda.

Pada Tabel 1 diatas bobot soal terlalu kecil, sehingga perlu ditingkatkan, misal menjadi bobot 10 atau 20. Jumlah skor yang diperoleh peserta didik pada soal tes uraian tergantung pada banyaknya langkah-langkah pengerjaan soal yang dijawab benar. Siswa yang mendapat skor 5 berbeda dengan siswa yang mendapat skor 9. Siswa yang mendapat skor 0 bukan berarti tidak mempunyai kemampuan sama sekali. Ada faktor yang mempengaruhi siswa pada saat mengerjakan soal ujian baik itu faktor psikologis maupun faktor lingkungan. Nilai skor antara siswa yang satu dengan siswa yang lain mempunyai jarak yang sama karena menggunakan alat ukur dan pedoman penskoran yang sama. 


\section{KESIMPULAN}

Berdasarkan pembahasan diatas diperoleh beberapa kesimpulkan sebagai berikut:

1. Soal tes digunakan untuk menguji kemampuan (domain kognitif) siswa atau untuk mengetahui hasil belajar peserta didik setelah mengikuti proses pembelajaran. Alat ukur dan pengukuran yang digunakan haruslah sama, sehingga diperoleh data pengukuran yang sama.

2. Skala data hasil tes pilihan ganda bukanlah skala nominal karena adanya perbedaan perolehan skor yang menjawab soal benar. Bukan juga skala rasio karena tidak ada nilai 0 mutlak. Peserta didik diuji menggunakan alat ukur dan pedoman penskoran yang sama sehingga mempunyai jarak yang sama. Jadi dapat disimpulkan bahwa skala data hasil tes pilihan ganda adalah skala interval.

3. Skala data hasil tes uraian bukanlah skala nominal karena adanya perbedaan perolehan skor menjawab langkah-langkah pengerjaan soal benar. Bukan juga skala rasio karena tidak ada nilai 0 mutlak. Peserta didik diuji menggunakan alat ukur dan pedoman penskoran yang sama sehingga mempunyai jarak yang sama. Jadi dapat disimpulkan bahwa skala data hasil tes uraian adalah skala interval.

\section{DAFTAR PUSTAKA}

Rofieq, A. (2002). Assesmen Pembelajaran di SD. Jakarta: Universitas Terbuka.

Suliyanto. (2006). Metode Riset Bisnis. Yogyakarta: Penerbit Andi.

Suliyanto. (2011). Perbedaan Pandangan Skala Likert Sebagai Skala Ordinal

Atau Interval. Makalah pada Seminar Nasional Statistika Universitas Dipenogoro, Semarang.

Susetyo, B. (2012). Statistika. Jakarta: Dirjen Pendidikan Islam Kemenag. 